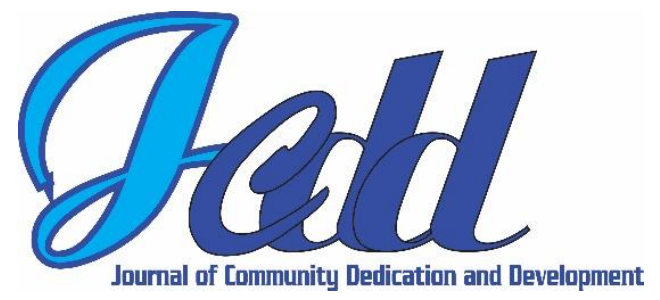

\title{
Optimalisasi Masyarakat Desa Namlea Dalam Menghadapi Tanggap Darurat Pandemi Covid-19
}

\author{
Susiati ${ }^{1}$, Saidna Zulfiqar Bin Tahir $^{2}$, Ibnu Hajar ${ }^{3}$, A. Yusdianti Tenriawali ${ }^{4}$, Musyawir ${ }^{5}$ \\ 1,2,3.4,5 Universitas Iqra Buru, Namlea, Indonesia \\ Email: susiatiuniqbu@gmail.com
}

\begin{abstract}
Abstrak
Tujuan pengabdian masyarakat ini, yakni memberikan edukasi dan sosialisasi dalam memahami bahaya, pencegahan, penularan, serta cara memutus mata rantai penyebaran covid-19. Metode yang digunakan dalam pengabdian masyarakat ini adalah berupa edukasi dan sosialisasi gaya hidup bersih dan sehat untuk mengantisipasi penyebaran covid-19 dengan tiga tahap, yakni tahap persiapan, tahap pelaksanaan, dan tahap evaluasi. Sasaran pelaksanaan kegiatan pengabdian masyarakat ini, yaitu warga Dusun Bara RT 01, RW 03, Desa Namlea, Kecamatan Namlea, Kabupaten Buru. Hasil kegiatan pengabdian masyarakat ini adalah warga mendapatkan pengetahuan melalui tahap edukasi dan sosialisasi dalam bentuk pembagian pamflet, masker gratis, serta pembuatan tempat cuci tangan. Dari hasil edukasi dan sosialisasi tersebut, warga Dusun Bara RT 01, $R W$ 03, Desa Namlea dapat mempraktekkan pola hidup bersih dan sehat, cara menggunakan masker, pengadaan tempat cuci tangan, menghindari kontak langsung dengan warga lain, mematuhi protokol kesehatan, mengetahui jenis masker sekali pakai dan jenis masker cuci ulang, menerapkan pola dan perilaku hidup sehat di masyarakat dengan mengkonsumsi makanan sehat secara seimbang.
\end{abstract}

Kata Kunci: optimalisasi, tanggap darurat, pandemi

\begin{abstract}
The aim of this community service is to provide education and outreach in understanding the dangers, prevention, transmission, and how to break the chain of the spread of covid19. The method used in this community service is in the form of education and socialization of a clean and healthy lifestyle to anticipate the spread of Covid-19 with three stages, namely the preparation stage, the implementation stage, and the evaluation stage. The targets of the implementation of this community service activity are residents of Bara Hamlet RT 01, RW 03, Namlea Village, Namlea District, Buru Regency. The result of this community service activity is that residents gain knowledge through the education and socialization stages in the form of distributing pamphlets, free masks, and making hand washing stations. From the results of this education and socialization, residents of Bara Hamlet RT 01, RW 03, Namlea Village can practice a clean and healthy lifestyle, how to use masks, provide a place to wash their hands, avoid direct contact with other residents, adhere to health protocols, know the types of disposable masks and the types of re-wash masks, adopt healthy lifestyle patterns and behaviors in the community by eating a balanced healthy diet.
\end{abstract}

Keywords: optimization, emergency response, pandemic 


\section{PENDAHULUAN}

Penyebaran virus corona saat ini tengah melanda dunia. Seluruh negara merasakan ganasnya virus ini. Virus ini dikenal dengan CoV (Coronaviruses), yakni salah satu jenis virus yang awal penyebabnya dari flu dan penyakit yang sangat ganas seperti Severe Acute Respiratory Syndrome (SARS-Cov) dan Middle East Respiratory Syndrome (MERS-CoV). Virus Corona atau lebih dikenal dengan Covid-19 merupakan jenis virus baru yang muncul atau ditemukan pada tahun 2019 dan belum pernah diidentifikasi dapat menyerang sebelumnya. Selain itu, virus corona atau covid-19 juga merupakan bagian dari virus yang dapat menginfeksi burung dan mamalia, termasuk manusia (Kurniawati \& Santosa, Farah Heniati Bahri, 2020).

Tempat pertama kali virus corona ditemukan, yakni di Kota Wuhan, China. Penyebaran virus ini sangat cepat hingga saat ini belum ditemukan vaksin ataupun penawarnya. Adapun korban akibat covid-19 ini sudah mencapai jutaan orang sampai meninggal dunia. Awal bulan Januari 2020, covid-19 sudah menyebar ke negara Indonesia. Pakar Epidemiologi Universitas Indonesia (UI), Pandu Riono, menuturkan bahwa tangga 2 Maret 2020 untuk pertama kalinya pemerintah mengumumkan melalui media massa bahwa terdapat dua kasus pasien positif covid19 di Indonesia. Hal ini dipertegas WHO, bahwa data per tanggal 2 Maret 2020 jumlah penderita sebanyak 90.308 terinfeksi covid-19.

Kasus pertama kali dari virus corona, yakni awal Maret dan sudah bertransmisi lokal dan bukan lagi penularan berskala dalam. Artinya, penyebaran virus tersebut masuk melalui pintu masuk di beberapa wilayah di Indonesia. Berbagai langkah telah digiatkan oleh pemerintah agar penyebaran virus tersebut berhenti seperti PSBB dan Social Distancing, tetapi langkah tersebut kurang diindahkan atau dilaksanakan oleh warga. Untuk menjawab permasalahan di atas, seyogyanya masyarakat harus menumbuhkan kesadaran diri baik secara pribadi maupun kelompok dalam menjaga pola hidup atau gaya hidup ke arah yang lebih bersih dan sehat. Kesadaran ini masih minim di tengah-tengah masyarakat. Untuk itu, pengabdian ini difokuskan pada kegiatan sosialisasi dan edukasi kepada masyarakat terkait kiat-kiat dalam tanggap darurat pandemi covid-19 seperti memberikan edukasi dan menyosialisasikan terkait pola hidup sehat. Suyatmin dan Sukardi dalam (Safitri \& Harun, 2021) menyatakan bahwa cara membiasakan pola hidup sehat pada masa pandemi covid-19 seperti saat ini dapat dilakukan dengan melakukan aktivitas fisik, konsumsi makanan bergizi, sayuran, dan buah-buahan. Kebiasaan hidup bersih dapat diawali dengan kegiatan sederhana seperti mencuci tangan sebelum makan, menyikat gigi, membersihkan setelah buang air kecil, mandi, membuang sampah di tempatnya, membatasi penggunaan plastik, menggunakan air bersih, dan sebagainya (Yufiarti et al., 2019). Membiasakan pola hidup sehat dan bersih ketika pandemi covid 19 seperti saat ini memang sangat penting. 
Adapun state of the art dari pengabdian ini adalah pengabdian dari Kiki Riski Ayu Kurniawati dkk (2020) dengan judul Sosialisasi Hidup Sehat di Tengah Wabah Virus Corona. Tujuan dari pengabdian tersebut adalah untuk memberikan pengetahuan dan kemampuan dalam mengantisipasi penyebaran covid-19. Adapun haslinya, yakni warga BTN Grand Muslim Cluster Istanbul Desa Terongtawah Kecamatan Labuapi Kabupaten Lombok Barat memiliki pengetahuan dan kemampuan untuk mengantisipasi penyebaran covid-19 serta lebih waspada dan tenang dalam menghadapi pandemi yang sedang berlangsung (Kurniawati \& Santosa, Farah Heniati Bahri, 2020).

Selanjutnya, pengabdian yang dilakukan oleh Nailul Mona (2020) dengan judul Konsep Isolasi dalam Jaringan Sosial untuk Meminimalisasi Efek Contagious (Kasus Penyebaran Virus Corona di Indonesia). Tujuan dilaksanakannya pengabdian tersebut adalah untuk menunjukkan efektivitas peran isolate yang menjalani social distancing dalam mencegah penularan virus corona secara contagious dengan metode analisis jaringan. Hasil penelitian menunjukkan bahwa jaringan sosial tanpa peran isolate memiliki ties dan kepadatan tinggi sehingga banyak peluang virus untuk menyebar pada anggota jaringan. Sedangkan jaringan sosial di mana banyak anggotanya melakukan isolasi memiliki ties lebih sedikit serta kepadatan rendah yang membuat peluang penyebaran virus antar anggota jaringan melalui ties menjadi lebih rendah (Nailul, 2020)

Pengabdian kepada masyarakat pula dilakukan oleh Winny Sunfriska Limbong, Mei Lyna Girsang, Ruth Donda Panggabean pada tahun 2020 dengan judul Sosialisasi Gaya Hidup Sehat Pada Masa Pandemi Covid-19 di Panti Asuhan Talenta Delpita Di Medan. Tujuan dilakukan pengabdian tersebut adalah untuk memberikan dampak yang positif terhadap kehidupan di Panti Asuhan Talenta Delpita dan sekitarnya. Hasil dari pengabdian tersebut masyarakat dapat mengimplementasikan gaya hidup sehat pada masa pandemic covid-19 baik utuk diri sendiri dan lingkungan sekitar, masyarakat menyadari pentingnya menjaga lingkungannya tetap bersih, masyarakat menyadari bahwa kebersihan itu adalah sebagian dari iman sehingga kebersihan harus dimulai dari diri-sendiri, dan masyarakat melakukan berjemur di rumah sekitar 10 menit dipagi hari, olahraga atau senam pagi di rumah masing-masing untuk meningkatkan daya tahan tubuh menjadi lebih optimal. Sosialisasi gaya hidup sehat pada masa pandemic Covid-19, yaitu dengan mengajak anak-anak untuk berperilaku hidup sehat di masa pandemi ini dengan mengenal mereka cara mencuci tangan yang benar, cara menggunakan masker dengan benar serta cara menerapkan protocol kesehatan pada masa new normal dan penutupan dengan mengakhiri rangkaian kegiatan , menygucapakan terimakasih banyak atas waktu dan sambutan yang telah diberikan (Limbong et al., 2020). Selain itu, terdapat pula penelitian yang dilakukan oleh Asep Ardiyanto, Veryliana Purnamasari, Sukamto, dan Eka Sari S. pada tahun 2020 dengan judul Analisis Perilaku Hidup Bersih dan Sehat di Era Pandemi Covid-19 Dosen PGSD. 
Tujuan penelitian ini adalah ingin mengetahui perilaku hidup bersih dan sehat di era pandemi covid-19 dosen PGSD, Fakultas IImu Pendidikan, Universitas PGRI Semarang. Hasil dari penelitian ini adalah dosen PGSD Universitas PGRI Semarang telah melaksanakan perilaku hidup bersih dan sehat baik sebelum maupun selama pandemi covid 19 yakni dengan tetap berolahraga dan menjaga pola hidup sehat dan bersih. Jenis olahraga yang banyak dilakukan selama masa pandemi covid 19 dengan prsentase tertinggi adalah Senam, Jogging dan Bersepeda. Sedangkan untuk aktivitas fisik di rumah dengan presentase tertinggi yang banyak dilakukan adalah membersihkan rumah dan memasak. Dengan menerapkan pola hidup bersih dan sehat serta rutin berolahraga rata-rata minimal 30 menit perhari dosen PGSD Universitas PGRI Semarang percaya diri bahwa dengan tubuh yang bugar sehat karena berolahraga akan terhindar dari pandemi covid 19 (Ardiyanto et al., 2020)

Perkembangan covid-19 begitu cepat penyebarannya dan tidak bisa terkendali. Tidak menutup kemungkinan akan menyebar di kabupaten lain, salah satunya di Kabupaten Buru. Langkah cepat dan tepat yang mesti digiatkan untuk menekan bertambahnya penyebaran virus ini, yakni giatkan pola hidup bersih, menjaga anggota keluarga kita, dan memberikan edukasi serta sosialisasi penting tentang covid-19. Salah satu langkah cepat ini dapat dilakukan dengan mulai dari masyarakat tempat tinggal kita seperti di kompleks perumahan. Namlea merupakan salah satu desa yang ada di Kabupaten Buru yang notabene masyarakatnya sudah hidup modern, artinya mereka sudah hidup konsumtif media massa baik melalui televisi, facebook, twitter dan lain-lain, tetapi kesadaran dan antisipasi masih sangat minim. Parahnya, mereka mudah terprovokasi oleh berita-berita palsu yang tersebar di beberapa media sosial sehingga kepercayaan masyarakat terhadap keberadaan virus ini sangat minim, akibatnya protokol kesehatan sering dilanggar atau tidak diterapkan dalam keseharian mereka. Permasalahan tadi terjadi pula pada warga Dusun Bara RT 01, RW 03, Desa Namlea.

Situasi di atas harus mendapat perhatian penuh dari pemerintah dan instansi atau lembaga terkait agar masyarakat dapat patuh dan memulai untuk menerapkan pola hidup sehat. Sehingga kami tim pelaksana pengabdian dari Universitas Iqra Buru menganggap perlu adanya sosialisasi dan edukasi yang intensif kepada masyarakat Indonesia terlebih pada warga Desa Namlea, Kabupaten Buru. Menurut data yang dilansir dari Satuan Tugas Percepatan Penanganan Covid-19 Provinsi Maluku, jumlah pasien positif corona aktif di Kabupaten Buru terus bertambah. Saat ini jumlah pasien yang sedang menjalani perawatan mencapai 76 orang. Untuk itu, penting untuk adanya edukasi dan sosialisasi sebagai salah satu solusi dalam menghadapi tanggap darurat pandemik covid-19. Berdasarkan hasil survei pada warga Dusun Bara RT 01, RW 03, tampak bahwa warga dominan belum memahami secara menyeluruh dan utuh terkait virus corona atau covid-19, dari hal tentang apa itu covid-19, bagaimana penyebarannya, serta bagaimana penanganannya, dan masih banyaknya para ibu yang secara 
psikologi cepat dan rentan tertekan dan panik akibatnya para ibu tersebut kurang berpikir jernih dalam menghadapi situasi covid-19. Dari hasil observasi inilah yang mendasari dilakukannya kegiatan pengabdian masyarakat dalam bentuk edukasi dan sosialisasi sebagai salah satu optimalisasi warga khususnya warga Desa Namlea dalam menghadapi tanggap darurat pandemik covid-19.

\section{METODE}

Adapun metode pelaksanaan kegiatan pengabdian masyarakat ini sebagai berikut

1. Tahap Persiapan

Pada tahap ini tim mengunjungi lokasi untuk melakukan observasi terkait sejauh mana kesiapan warga dalam menghadapi situasi pandemik covid-19. Selain itu, tim juga mengobservasi profil Dusun Bara RT 01, RW 03 dan menyiapkan sarana prasarana yang dibutuhkan dalam kegiatan pengabdian masyarakat.

2. Tahap Pelaksanaan

Memberikan edukasi dan sosialisasi mengenai covid-19 dan cara jitu mengantisipasi penyebaran covid-19 dalam bentuk pamflet yang menarik sehingga dapat dibaca serta mudah dipahami oleh warga Dusun Bara RT 01, RW 03. Selain itu, tim juga memberikan edukasi dalam mengantisipasi pencegahan penyebaran covid-19 dengan cara membuat tempat untuk cuci tangan, cara mencuci tangan, cara menggunakan masker, cara membedakan masker yang sekali pakai dan masker yang dapat dicuci ulang.

3. Tahap evaluasi pelaksanaan dan program di lapangan setelah kegiatan ini selesai dilaksanakan adalah dengan terus membangun komunikasi dan memberikan informasiinformasi yang penting pada warga Dusun Bara RT 01, RW 03 melalui media sosial.

\section{HASIL DAN PEMBAHASAN}

Dusun Bara RT 01, RW 03 merupakan salah satu dusun yang ada di Desa Namlea. Dusun Bara RT 01, RW 03 berjumlah 85 KK. Hasil dari pelaksanaan kegiatan pengabdian ini dibagi ke dalam 2 kegiatan, yaitu tahap persiapan dan tahan pelaksanaan.

\section{Tahap persiapan}

Tujuan dari tahap persiapan ini, yakni tim mengobservasi awal, melihat situasi dan kondisi warga bertujuan untuk melihat kondisi sosial warga Dusun Bara RT 01, RW 03, baik dari pekerjaan, profesi, pendidikan, serta ekonominya. Kemudian, tim menetapkan pendekatan sosialisasi dan edukasi merupakan pilihan yang tepat dalam memberikan pengetahuan mengenai covid-19 serta cara-cara mengantisipasi penyebaran covid-19. 
Setelah pendekatan edukasi dan sosialisasi dipilih, selanjutnya tim menyiapkan sarana dan prasarana pendukung pelaksanaan pengabdian.

\section{Tahap pelaksanaan}

Pada tahap pelaksanaan yang dilakukan pertama adalah edukasi dan sosialisasi mengenai covid-19 dan bagaimana cara-cara untuk mengantisipasi covid-19. Pendekatan persuasif merupakan pilihan tim dalam edukasi dan sosialisasi, yakni dengan menggunakan media pamflet bergambar kartun. Hal ini dilakukan agar dapat dikonsumsi dan dipahami oleh berbagai kalangan dari mulai kana-kanak sampai orang dewasa. Pada tahap edukasi dan sosialisasi ini lebih berfokus pada pemerian ilmu pengetahuan kepada para ibu-ibu warga Dusun Bara RT 01, RW 03, Desa Namlea. Hal ini dilakukan karena aktivitas dan peran seorang ibu dalam rumah tangga leboh dominan, sehingga dengan pemerian edukasi dan sosialisasi yang tepat kepada ibu-ibu, diharapkan bisa lebih mengontrol semua anggota keluarga. Upaya pemerian edukasi dan sosialisasi kepada para lbu-ibu ini digiatkan lebih dulu karena tahapan antisipasi yang paling utama dilakukan dalam mencegah penyebaran covid-19 adalah di lingkungan keluarga, yakni menjaga dan melaksanakan pola hidup bersih anggota keluarga.

Pamflet dalam tahap sosialisasi dilakukan 3 bentuk, yakni mendeskripsikan tentang apa itu covid-19, cara penyebarannya, serta cara mengantisipasi agar tidak terinfeksi. Pamflet tersebut di bagi ke tiap rumah dan menempelnya pada dinding-dinding rumah warga. Kemudian pada pamflet selanjutnya, tim mendeskripsikan ke dalam media berbasis gambar kartun cara menerapkan pola hidup bersih, yakni cara mecuci tangan, cara berkontak dengan warga lain, dan cara mengonsumsi makanan seperti buah-buahan. Selanjutnya, pamflet ke 3 , yakni mendeskripsikan cara-cara menggunakan masker yang baik dan benar. Ketiga jenis pamflet tersebut disesuaikan dengan standar kesehatan.

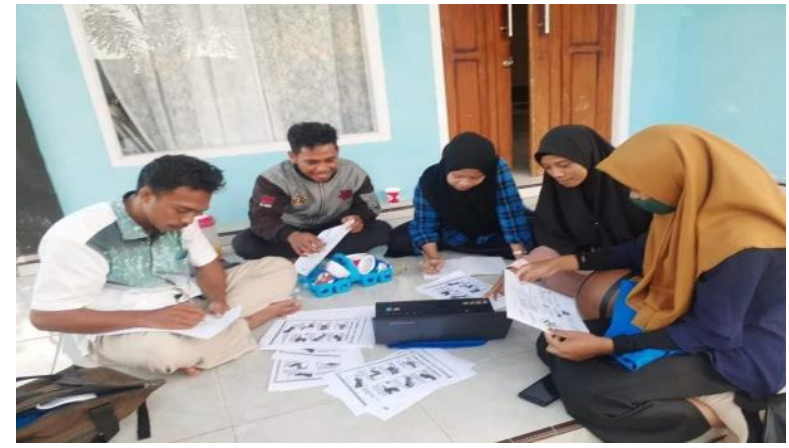

Gambar 1. Pembuatan Pamflet

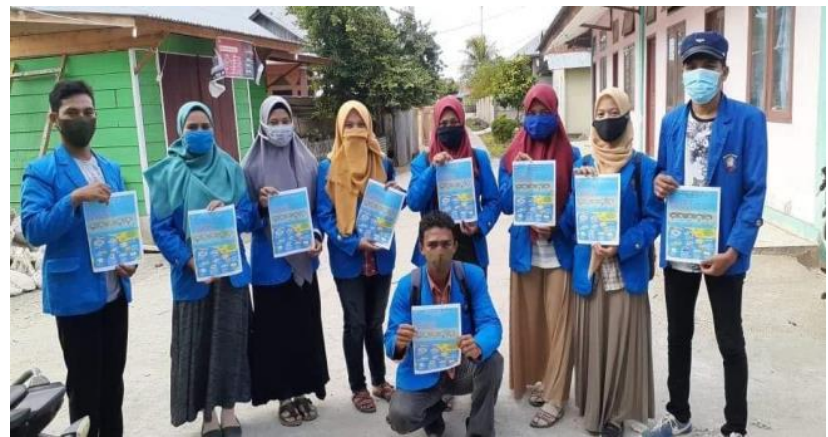

Gambar 2. Pembagian Pamflet Minggu Pertama 


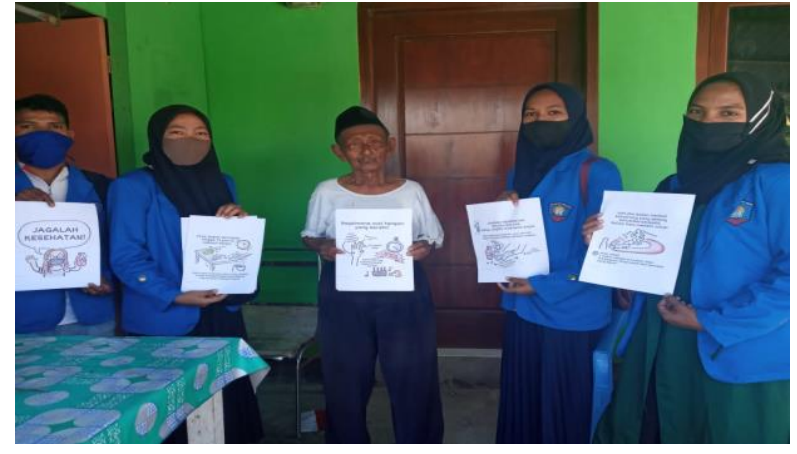

Gambar 3. Pembagian Pamflet Minggu Kedua

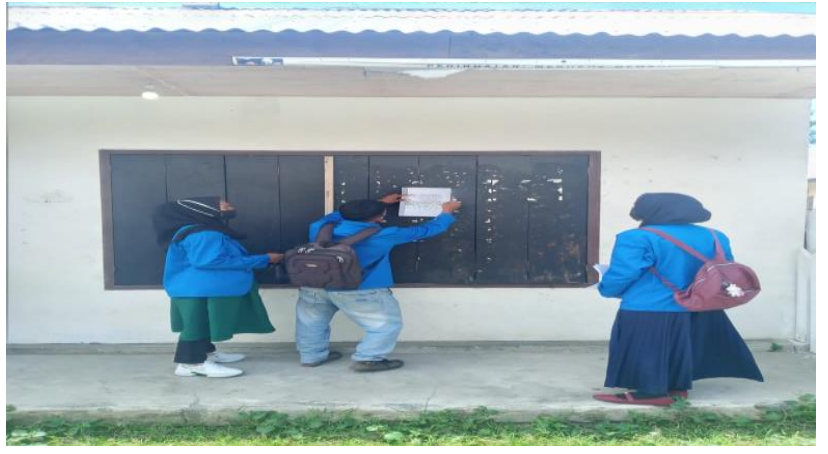

Gambar 4. Penempelan Pamflet di Rumah Warga

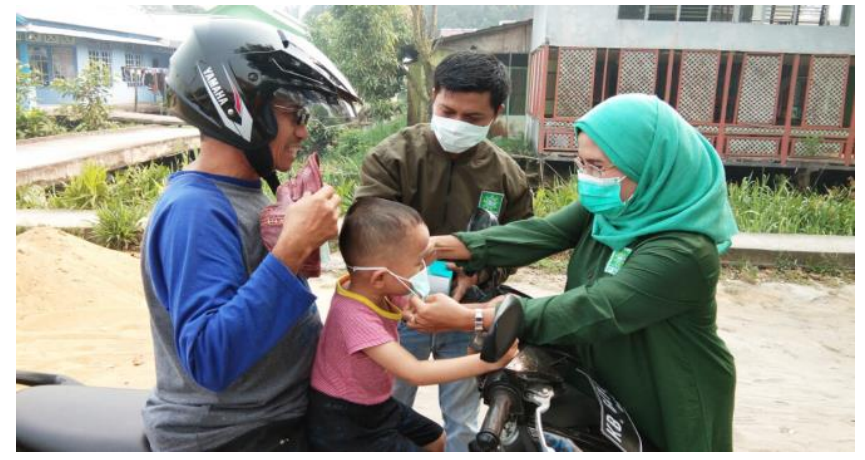

Gambar 5. Pembagian masker dan handsanitizer

Tim dalam menyebarluaskan pamflet melakukan sistem dari rumah ke rumah (door to door), tim setiap minggu selama 3 minggu melakukan pembagian pamflet. Jika tim mendapatkan respon berupa pertanyaan dari para lbu-ibu, tim langsung memberikan penjelasan sesuai dengan inti sari pertanyaan dari warga. Tim memilih memakai sistem dari rumah ke rumah karena untuk menghindari kerumunan atau perkumpulan, yakni social distancing serta untuk menjamin agar warga lebih leluasa mengajukan pertanyaan atau tanggapn dengan baik dari tim.

Tahap kedua, yakni tim memberikan edukasi terkait cara-cara meminimalisir penyebaran virus corona, yakni dengan menyediakan wadah atau tempat cuci tangan, pembagian masker secara gratis, dan penggunaan sabun atau handsanitizer. Adapun alat dan bahan tersebut didapat dari bantuan dinas-dinas terkait Kabupaten Buru selain itu warga ikut berpartisipasi dalam pembuatan tempat cuci tangan yang dilakukan dengan meletakkan beberapa ember di setiap blok untuk membiasakan warga mencuci tangannya sebelum menuju ke rumah masing-masing dan untuk digunakan oleh warga atau pejalan kaki. Pembagian masker dilakukan oleh tim dengan mengantarkan dari rumah ke rumah warga. 


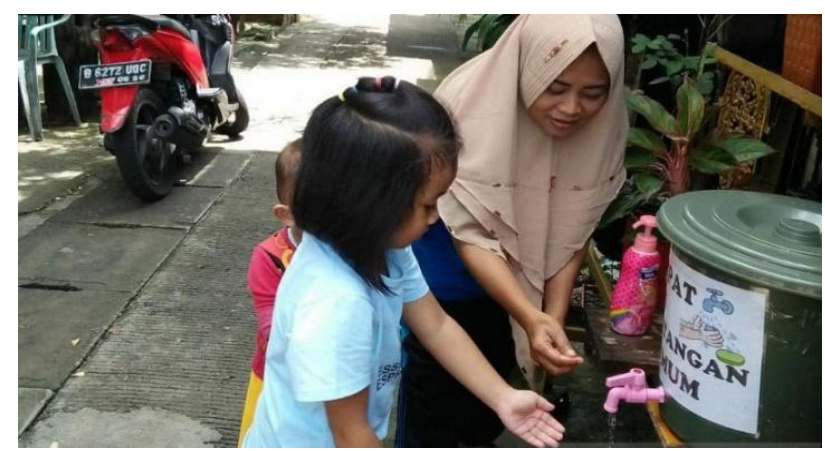

Gambar 6. Pengadaan Tempat Cuci Tangan

Tahap ketiga dari pelaksanaan kegiatan ini adalah melaksanakan webiner dengan menghadirkan para narasumber dari Ketua Satgas Covid-19 Kabupaten Buru, Kepala Dinas Kesehatan Kabupaten Buru, dan Kepala BNPB Kabupaten Buru. Peserta dalam webinar ini adalah mahasiswa dan warga Dusun Bara RT 01, RW 03, Desa Namlea. Adapun materimateri yang dipaparkan oleh para narasumber adalah berbagai edukasi menjaga dan menerapkan pola hidup sehat dan bersih. Dalam webinar ini pula para warga dipersilahkan untuk bertanya tentang hal-hal terkait covid-19.
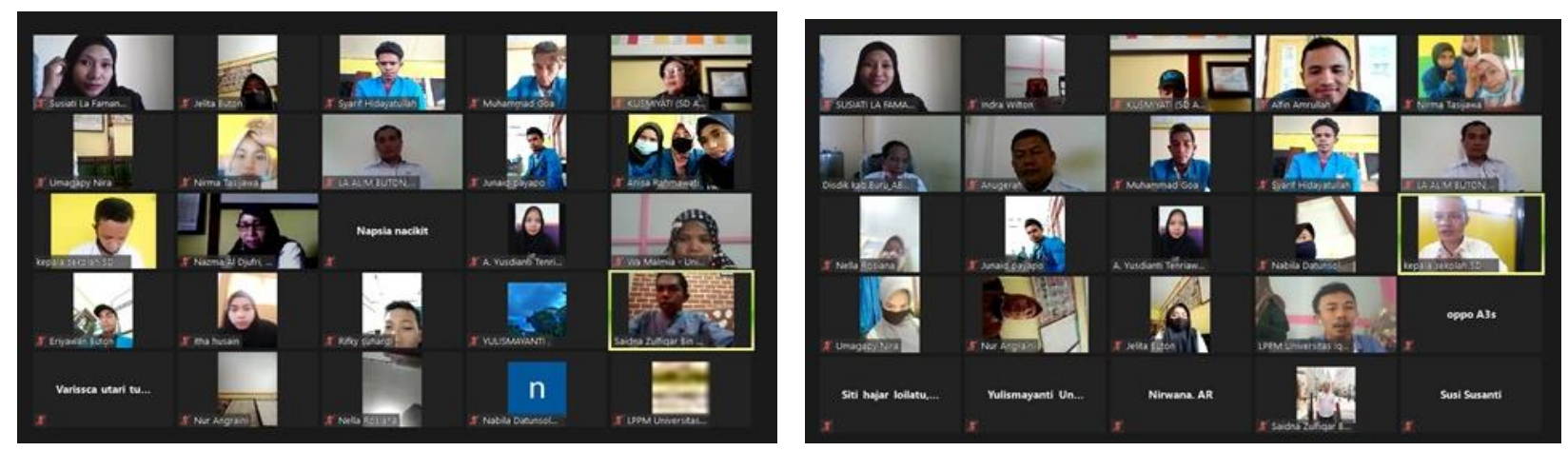

Gambar 7. Webinar Edukasi dan Sosialisasi Tanggap Darurat Pandemi Covid-19

Segala usaha yang telah dilakukan oleh tim pengabdi, dengan penuh suka cita mendapatkan respon yang positif dari semua warga Dusun Bara RT 01, RW 03, Desa Namlea dan warga dengan suka cita melakukan semua langkah-langkah pencegahan atau antisipasi yang telah diinformasikan oleh tim pengabdi. Hasil dari pengabdian ini adalah untuk memberikan pengetahuan dan kemampuan kepada warga Dusun Bara RT 01, RW 03, Desa Namlea dalam menghadapi penyebaran covid-19 untuk selalu waspada dan tenang dalam menghadapi pandemi yang tengah terjadi. 


\section{KESIMPULAN}

Berdasarkan hasil dan pembahasan yang sudah disampaikan pada pelaksanaan pengabdian masyarakat terkait edukasi dan sosialisasi covid-19, diperoleh bahwa warga Dusun Bara RT 01, RW 03, Desa Namlea, Kabupaten Buru mendapatkan pengetahuan melalui tahap edukasi dan sosialisasi dalam bentuk pembagian pamflet, masker gratis, serta pembuatan tempat cuci tangan. Dari hasil edukasi dan sosialisasi tersebut, warga Dusun Bara RT 01, RW 03, Desa Namlea dapat mempraktekkan pola hidup bersih dan sehat seperti cara mencuci tangan dengan baik dan benar, cara menggunakan masker, pengadaan tempat cuci tangan, menghindari kontak langsung dengan warga lain, mematuhi protokol kesehatan, mengetahui jenis masker sekali pakai dan jenis masker cuci ulang, menerapkan pola dan perilaku hidup sehat di masyarakat dengan mengkonsumsi makanan sehat secara seimbang, berolah raga dan jam tidur yang teratur, melakukan pemeriksaan kesehatan rutin di Pusat Layanan Kesehatan terdekat, warga dilatih psikologinya untuk lebih menyesuaikan diri dengan pandemi covid-19.memiliki pengetahuan dan kemampuan untuk mengantisipasi penyebaran virus serta lebih waspada dan tenang dalam menghadapi pandemi yang sedang berlangsung.

\section{UCAPAN TERIMA KASIH}

Ucapan terima kasih kepada Rektor Universitas Iqra Buru atas dukungan materil dan moril yang telah diberikan hingga selesainya kegiatan pengabdian ini. Tim pengabdi menghaturkan terima kasih kepada Kepala Lembaga Penelitian dan Pengabdian kepada Mayarakat (LPPM) Universitas lqra Buru atas pastisipasinya dalam kegiatan pengabdian ini. Selanjutnya, tim pengabdi mengucapkan terima kasih kepada para warga Dusun Bara RT 01, RW 03, Desa Namlea yang telah kooperatif dan sportif dalam jalannya kegiatan pengabdian ini.

\section{REFERENSI}

Ardiyanto, A., Purnamasari, V., Sukamto, \& Eka Sari S. (2020). Analisis Perilaku Hidup, Bersih dan Sehat di Era Pandemi Covid-19 Dosen PGSD. Jendela Olahraga, 05(02), 131-140.

Kurniawati, K. R. A., \& Santosa, Farah Heniati Bahri, S. (2020). Sosialisasi Hidup Sehat di Tengah Wabah Virus Corona. JPMB: Jurnal Pemberdayaan Masyarakat Berkarakter, 3(1), 58-65.

Limbong, W. S., Girsang, M. L., \& Ruth Donda Panggabean. (2020). Sosialisasi Gaya Hidup Sehat Pada Masa Pandemi Covid-19 di Panti Asuhan Talenta Delpita Di Medan. Abdimas Mutiara, 1(2), 199-205.

Nailul, M. (2020). Konsep Isolasi da lam Jaringan Sosial untuk Meminimalisasi Efek Contagious (Kasus Penyebaran Virus Corona di Indonesia). Jurnal Sosial Humaniora Terapan, 2(2), $117-125$. 
Safitri, H. I., \& Harun. (2021). Membiasakan Pola Hidup Sehat dan Bersih pada Anak Usia Dini Selama Pandemi Covid-19. Obsesi, 5(1), 385-394.

Yufiarti, Y., Edwita, \& Suharti. (2019). Healt Promotion Program (JUMSIH); To Enhance Children's Clean and Healthy Living Knowledge. Pendidikan Usia Dini, 13(2), 341-355. 